\title{
Permanent occurrence of Raphidiopsis raciborskii and cyanotoxins in a subtropical reservoir polluted by domestic effluents (Itupararanga reservoir, São Paulo, Brazil)
}

\section{Leila Dos Santos Machado ( $\square$ leila.machado@unesp.br)}

UNESP: Universidade Estadual Paulista Julio de Mesquita Filho https://orcid.org/0000-0003-34914903

\section{Fabiane Dörr}

University of Sao Paulo: Universidade de Sao Paulo

\section{Felipe Augusto Dörr}

University of Sao Paulo: Universidade de Sao Paulo

\section{Daniele Frascareli}

UNESP: Universidade Estadual Paulista Julio de Mesquita Filho

\section{Darllene S. Melo}

UNESP: Universidade Estadual Paulista Julio de Mesquita Filho

Erik S.J. Gontijo

UNESP: Universidade Estadual Paulista Julio de Mesquita Filho

\section{Kurt Friese}

Helmholtz-Centre for Environmental Research - UFZ: Helmholtz-Zentrum fur Umweltforschung UFZ

\section{Ernani Pinto}

University of Sao Paulo: Universidade de Sao Paulo

\section{André Henrique Rosa}

UNESP: Universidade Estadual Paulista Julio de Mesquita Filho

\section{Marcelo M. Pompêo}

University of Sao Paulo: Universidade de Sao Paulo

\section{Viviane Moschini-Carlos}

UNESP: Universidade Estadual Paulista Julio de Mesquita Filho

\section{Research Article}

Keywords: Eutrophication, saxitoxin, microcystin, biomass, blooms, aquatic ecosystem

Posted Date: May 14th, 2021 
DOl: https://doi.org/10.21203/rs.3.rs-404397/v1

License: (c) (i) This work is licensed under a Creative Commons Attribution 4.0 International License. Read Full License 


\section{Abstract}

Toxic cyanobacteria blooms are a frequent problem in subtropical reservoirs and freshwater systems. The purpose of this study was to investigate the occurrence of potentially toxic cyanobacteria and the environmental conditions associated with the presence of cyanotoxins in a Brazilian subtropical reservoir. Five collections were carried out at seven sampling locations in the reservoir, during the rainy and dry seasons, between the years 2016 and 2017. There was permanent occurrence of Raphidiopsis raciborskii (Woloszynska) Aguilera, Berrendero Gómez, Kastovsky, Echenique \& Salerno, ranging between dominant and abundant, with an average biomass of $38.8 \pm 29.9 \mathrm{mg} \mathrm{L}^{-1}$. Also abundant were $D$. solitarium, $D$. planctonicum, $P$. isothrix, and $A$. gracile. Saxitoxin (STX) was detected in all the collected samples $(0.11 \pm$ $\left.0.05 \mu \mathrm{g} \mathrm{L}^{-1}\right)$. Microcystin (MC) was also detected, but at lower concentrations $\left(0.01 \pm 0.0 \mu \mathrm{g} \mathrm{L}^{-1}\right)$. Low availability of $\mathrm{NO}_{3}{ }^{-}$and phosphorus limitation had significant effects on the $R$. raciborskii biomass and the levels of STX and MC. It was observed that $R$. raciborskii was sensitive to thermal stratification, at the same time that STX levels were higher. This suggested that STX was produced under conditions that restricted the growth of $R$. raciborskii. These are important findings, because they add information about the permanent occurrence of STX and $R$. raciborskii in an aquatic ecosystem limited by phosphorus, vulnerable to climatic variations, and polluted by domestic effluents.

\section{Introduction}

Tropical and subtropical regions are those most affected by the occurrence of potentially toxic cyanobacteria blooms (WHO 2017). Freshwater ecosystems in these regions are environments conducive to the occurrence of cyanobacteria and cyanotoxins, because in addition to the favorable climate, they frequently contain high levels of nutrients (Mowe et al. 2015).

Brazil was the first country to create specific legislation containing guidelines aimed at controlling cyanotoxins and cyanobacteria in drinking water (Bittencourt-Oliveira et al. 2014). This occurred after the reported intoxication of 131 chronic kidney disease patients at a hemodialysis clinic in the city of Caruarú (Pernambuco State, Brazil), due to contamination of the water by microcystins (Carmichael et al. 2001). Studies have reported the occurrence of blooms of potentially toxic species in different regions of Brazil, mainly associated with the presence of $R$. raciborskii and Microcystis spp (Figueredo \& Giani 2009; Moschini-Carlos et al. 2009; Cunha \& Calijuri 2011b; Bittencourt-Oliveira et al. 2014; Fonseca et al. 2014; Nishimura et al. 2014; Machado et al. 2016; Casali et al. 2017; Santos et al. 2018; Vicentin et al. 2018; Rodrigues et al. 2019). The identified cyanotoxins included saxitoxins, microcystins, and cylindrospermopsin (Molica et al. 2002; Moschini-Carlos et al. 2009; Bittencourt-Oliveira et al. 2014; Casali et al. 2017; Pedrosa et al. 2020).

Toxic cyanobacteria blooms in eutrophic reservoirs represent a major public health problem. Pedrosa et al. (2020) reported that saxitoxin (STX) had a synergistic effect in Zika virus infections in Northeast Brazil, even at concentrations considered safe $\left(<3.00 \mu \mathrm{g} \mathrm{L}^{-1}\right)$. Facciponte et al. (2018) investigated the exposure route of aerosolized STX, showing contamination of the human respiratory tract. Christensen 
and Khan (2020) reported several other routes of exposure to this toxin, leading to lethal and sublethal effects, together with bioaccumulation, due to different types of direct and indirect contact.

The occurrence of microcystins (MC) has been associated with high concentrations of nitrogen, with blooms generally occurring during the rainy season (Mowe et al. 2015). Worldwide, the taxa frequently identified in blooms with the presence of MC are Microcystis aeruginosa, M. protocystis, M. panniformis, Plantothrix agardhii, P. isothrix, and Dolichospermum (Molica et al. 2002; Moschini-Carlos et al. 2009; Sant'Anna et al. 2011; Paerl \& Paul, 2012; Merel et al. 2013; Bittencourt-Oliveira et al. 2014; Funari et al. 2017; Huisman et al. 2018; Pham et al. 2020). Blooms dominated by these species are more frequent in the summer, when the warm climate favors an increase of biomass and the occurrence of cyanotoxins tends to be higher (Trung et al. 2018). Although the levels of cyanotoxins are not strongly correlated with biomass increase, the production of $\mathrm{MC}$ can be stimulated in the presence of some chlorophytes (Bittencourt-Oliveira et al. 2015). In addition to allelopathic interactions, herbicides used in agriculture can be carried to aquatic ecosystems and favor the production of cyanotoxins (Brêda-Alves et al. 2020).

The occurrence of STX, produced by toxic strains of $R$. raciborskii, is related to high temperatures, being common in periods of drought and low nitrogen availability (Mowe et al. 2015). The ability to fix atmospheric nitrogen is one of the main adaptations of $R$. raciborskii, enabling its growth in environments limited by phosphorus (Kenesi et al. 2009; Piccini et al. 2011). This allows the maintenance of these species in different environments, despite not necessarily being correlated to environmental variables (Figueredo \& Giani 2009). In addition, some studies mention the allelopathic effect of $R$. raciborskii, inhibiting the development of species of the genus Microcystis, favoring monospecific blooms (Mello et al. 2012). Furthermore, its sensitivity is related to stratification of the water column and flushing (Reynolds et al., 2002; Padisák et al., 2009). However, the many ecophysiological adaptations reflect the high genetic variability of this species, accounting for its wide occurrence in different regions of the world (Piccini et al. 2011; Antunes et al. 2015; Vanderley et al. 2021).

The problem of eutrophication is global, with widespread occurrence of potentially toxic species, highlighting the need to understand the most important environmental factors influencing this phenomenon (Moschini-Carlos et al. 2009, 2010; Yamamoto et al. 2011; Paerl \& Paul, 2012; Merel et al. 2013; Beghelli et al. 2016; Machado et al. 2016; Huisman et al. 2018; Pompêo et al. 2021). Such studies are crucial to support strategies for the management of these environments, aiming at achieving good ecological status and guiding public health actions (Cardoso-Silva et al. 2015; Pompêo et al. 2021). Therefore, in order to better understand the dynamics of cyanobacteria in an eutrophic subtropical reservoir, the aims of this study were to i) investigate the occurrence of cyanotoxins (microcystin and saxitoxin), ii) elucidate the relationship between cyanotoxins and the cyanobacteria biomass, and iii) identify in situ the environmental conditions that significantly influence the presence of cyanotoxins.

\section{Materials And Methods}

Study area 
The Itupararanga reservoir is located in the southeastern region of São Paulo State, Brazil (Fig. 1). The main channel of the reservoir is $26 \mathrm{~km}$ long and the average depth is $7.8 \mathrm{~m}$, reaching $21 \mathrm{~m}$. The climate in the region is typically subtropical and the average temperature varies between 18 and $22{ }^{\circ} \mathrm{C}$ (Melo et al., 2019).

Approximately $63 \%$ of the water of this reservoir is used for public supply in several cities located in its vicinity, serving around 800,000 people (Pedrazzi et al. 2013; Rosa et al. 2015). Recent studies have reported significant degradation of the reservoir water quality, due to inflows of domestic effluents in the fluvial region (Cunha \& Calijuri 2011a; Taniwaki et al. 2013; Beghelli et al. 2016; Melo et al. 2019). During the period of sample collection, the reservoir was characterized as super-eutrophic (Melo et al. 2019), based on the trophic status index model adapted by Cunha et al. (2013) for tropical and subtropical reservoirs.

Samples were collected at seven points (P1-P7) along the longitudinal axis of the reservoir (Fig. 1). The choice of locations considered the characteristics of use and occupation of the margins, as described by Rosa et al. (2015). Five collections were performed during the rainy and dry seasons, in the years 2016 and 2017 (December 2016, March 2017, August 2017, October 2017, and December 2017). The rainy season was from October to March and the dry season was from April to September (Melo et al. 2019).

Data reported previously for the Itupararanga reservoir (Melo et al. 2019) were used as a reference for the limnological characterization of the water, considering the following parameters: total nitrogen (TN), nitrite $\left(\mathrm{NO}_{2}{ }^{-}\right)$, nitrate $\left(\mathrm{NO}_{3}{ }^{-}\right)$, ammonium $\left(\mathrm{NH}_{4}{ }^{+}\right)$, total phosphorus (TP), orthophosphate $\left(\mathrm{PO}_{4}{ }^{3}\right)$, chlorophyll-a (Chl-a), euphotic zone (EZ), depth, temperature $(T)$, pH, electrical conductivity (EC), turbidity (TURB), and redox potential (Eh).

For quantitative analysis of phytoplankton, integrated samples of the water column were collected with a plastic hose (1 $\mathrm{m}$ length) and were fixed with $1 \%$ acetic lugol. The identification of cyanobacteria was based on the studies of Komárek \& Anagnostidis $(1999,2005)$, Sant'Anna et al. $(2004,2006,2012)$, and Nogueira et al. (2011). Counting was performed as described by Utermöhl (1958), using an inverted Zeiss AxioVert microscope. The biovolume was determined as described by Hillebrand et al. (1999) and Sun \& Liu (2003). Phytoplankton biomass was estimated according to Wetzel and Likens (2000), where $1 \mathrm{~mm}^{3}$ $\mathrm{L}^{-1}=1 \mathrm{mg} \mathrm{L}^{-1}$. Species were considered abundant when their biomass represented more than $5 \%$ of the total biomass.

Samples were collected for analysis of free STX and MC present in the reservoir water. In the laboratory, the samples were filtered using glass fiber filters (Whatman GFC) with pore size of $1.2 \mu \mathrm{m}$. The STX content was determined by enzyme-linked immunosorbent assay (ELISA), using the Saxitoxin Plate Kit (Beacon Analytical Systems, USA), according to the manufacturer's recommendations.

The analysis of microcystins was performed by liquid chromatography coupled with mass spectrometry (LC-MS). For this, a $400 \mathrm{~mL}$ volume of each sample was submitted to solid phase extraction (SPE) using 500 mg Sep-Pak C18 6cc Vac cartridges (Waters, USA), according to the methodology described by Kim 
et al. (2009). The cartridges were previously conditioned with $10 \mathrm{~mL}$ of HPLC grade methanol, followed by $10 \mathrm{~mL}$ of Milli-Q water. After eluting the samples, the cartridges were cleaned with $10 \mathrm{~mL}$ of Milli-Q water and $10 \mathrm{~mL}$ of $20 \%$ methanol. Finally, the analytes of interest were eluted with $10 \mathrm{~mL}$ of $80 \%$ methanol and the eluate was dried at $35^{\circ} \mathrm{C}$, under nitrogen. The dry material was resuspended in $1 \mathrm{~mL}$ of $70 \%$ methanol and filtered through a $0.45 \mu \mathrm{m}$ PVDF membrane (Millipore, USA). The analysis employed a 1260 Infinity chromatograph (Agilent Technologies, USA), which was coupled to a triple quadrupole mass spectrometer (6460 Triple Quad LC/MS, Agilent Technologies, USA) equipped with electrospray ionization (ESI) and operated in positive mode at $3500 \mathrm{~V}$ (The Supplementary Information (IS) Table 1-2 and Fig. 1-2 supports this analysis).

The inclusion and exclusion criteria for the environmental variables used in the statistical analysis were based on the results obtained using the Pearson linear correlation test. The entire matrix of the set of physical, chemical, and biological water data was used, including cyanobacteria identified with abundance $>5 \%$. The classification of the magnitude of the coefficients was based on Cohen (1988). Next, canonical correspondence analysis (CCA) was used to identify the environmental variables and species correlated to STX and MC. For this, the data set was treated by $\log 10$ transformation. In order to identify the environmental variables that had a significant effect in the CCA model, the scores were subjected to analysis of variance (ANOVA, $p<0.05$ ). A simple linear regression analysis was then performed, according to the patterns observed in the fitted CCA model, in order to determine the effects of the most significant environmental variables on the occurrence of cyanotoxins. All the analyses were performed using the $\mathrm{R}^{\circledR}$ 3.4.0 Vegan 2.5-2 software package (Oksanen et al. 2018).

\section{Results}

The Cyanophyceae were major contributors to the biomass of the phytoplankton community in the Itupararanga reservoir. Among all groups, cyanobacteria represented $40.3 \%$ of the total biomass, with higher levels at the end of the dry period (August 2017) and the beginning of the rainy period (October 2017) (Fig. 2). Among the abundant species identified, R. raciborskii was dominant in December 2016 and March 2017, with its occurrence remaining constant in the other collections (Fig. 3, Table 1). $R$. raciborskii showed permanent occurrence in the reservoir, with no significant seasonal variations of its biomass (mean $38.8 \pm 29.9 \mathrm{mg} \mathrm{L}^{-1}$ ). The apparently seasonal species included Phormidium aerugineocaeruleum (Gomont) Anagnostidis \& Komárek (mean $73.5 \pm 89.6 \mathrm{mg} \mathrm{L}^{-1}$ ), which only occurred at points P6 and P7, in August 2017. Other abundant species were Dolichospermum solitarium (Klebahn) Wacklin,

L. Hoffmann \& Komárek (mean $41.3 \pm 73.5 \mathrm{mg} \mathrm{L}^{-1}$ ), Dolichospermum planctonicum (Brunnthaler) Wacklin, L. Hoffmann \& Komárek (mean $36.5 \pm 60.3 \mathrm{mg} \mathrm{L}^{-1}$ ), Planktothrix isothrix (Skuja) Komárek \& Komárková (mean $25.8 \pm 29.3 \mathrm{mg} \mathrm{L}^{-1}$ ), and Aphanizomenon gracile Lemmermann (mean $14.7 \pm 24 \mathrm{mg} \mathrm{L}^{-}$ 1) (Fig. 3, Table 1).

Between the dry period (August 2017) and the beginning of the rainy period (October 2017), the cyanobacteria composition altered, with abundance of the species $D$. solitarium, P. isothrix, and A. gracile, 
in addition to $R$. raciborskii (Fig. 3).

The average cyanobacteria biomass varied among the sampling periods, indicating a seasonal response of these organisms (Fig. 4a). Spatial heterogeneity of the reservoir was also evident, since the average cyanobacteria biomass varied among the sampling points (Fig. 4a).

Free STX was detected, with an average concentration of $0.11 \pm 0.05 \mu \mathrm{g} \mathrm{L}^{-1}$ over the five collections. Among the MC variants evaluated, only MC-LR was detected at low concentrations $\left(0.01 \pm 0.0 \mu \mathrm{g} \mathrm{L}^{-1}\right)$ (Table 1).

Although both cyanotoxins were detected at low concentrations, the patterns of occurrence were different (Fig. 4b, Table 1). There was permanent presence of STX and MC-LR, with the compounds occurring in all five collections between December 2016 and December 2017. The lowest levels of STX were observed in August 2017, when the biomass values were also lower (Fig. 4b).

The environmental variables that showed significant effects in the CCA were $\mathrm{TN}, \mathrm{NO}_{2}{ }^{-}, \mathrm{NO}_{3}{ }^{-}$and $\mathrm{PO}_{4}{ }^{3-}$ (Table 1). The model provided high explanatory power, with the first two axes explaining $79.5 \%$ of the data variation ( $42.06 \%$ by axis 1 and $37.44 \%$ by axis 2 ) (Fig. 5 ).

\begin{tabular}{|lllll|}
\hline Variables & avg. & min. & max. & SD \\
\hline $\mathrm{TN}\left(\mu \mathrm{g} \mathrm{L}^{-1}\right)$ & 484,66 & 166,0 & 1210,00 & 215,16 \\
\hline $\mathrm{NO}_{2}-\left(\mu \mathrm{g} \mathrm{L}^{-1}\right)$ & 2,44 & 0,40 & 10,80 & 2,36 \\
\hline $\mathrm{NO}_{3}-\left(\mu \mathrm{g} \mathrm{L}^{-1}\right)$ & 81,09 & 7,90 & 295,80 & 83,22 \\
\hline $\mathrm{PO}_{4}{ }^{3}-\left(\mu \mathrm{g} \mathrm{L}^{-1}\right)$ & 22,50 & 3,80 & 60,40 & 18,66 \\
\hline $\mathrm{STX}\left(\mu \mathrm{g} \mathrm{L}^{-1}\right)$ & 0,11 & 0,04 & 0,21 & 0,05 \\
\hline $\mathrm{MC}-\mathrm{LR}\left(\mu \mathrm{g} \mathrm{L}^{-1}\right)$ & 0,01 & 0,00 & 0,02 & 0,00 \\
\hline Aphanizomenon gracile $\left(\mathrm{mg} \mathrm{L}^{-1}\right)$ & 14,70 & 0,13 & 80,81 & 24,06 \\
\hline Raphidiopsis raciborskii $\left(\mathrm{mg} \mathrm{L}^{-1}\right)$ & 38,80 & 3,43 & 119,76 & 29,99 \\
\hline Dolichospermum planctonicum $\left(\mathrm{mg} \mathrm{L}^{-1}\right)$ & 36,54 & 3,00 & 143,22 & 60,37 \\
\hline Dolichospermum solitarium $\left(\mathrm{mg} \mathrm{L}^{-1}\right)$ & 41,32 & 0,31 & 290,57 & 73,56 \\
\hline Phormidium aerugineo - caeruleum $\left(\mathrm{mg} \mathrm{L}^{-1}\right)$ & 73,57 & 2,75 & 174,36 & 89,64 \\
\hline Planktothrix isothrix $\left(\mathrm{mg} \mathrm{L}^{-1}\right)$ & 25,81 & 1,35 & 100,30 & 29,37 \\
\hline
\end{tabular}


Table 1 Average (avg), minimum (min), maximum (max), and standard deviation (SD) values for the variables analyzed using CCA: total nitrogen $(\mathrm{TN})$, nitrite $\left(\mathrm{NO}_{2}{ }^{-}\right)$, nitrate $\left(\mathrm{NO}_{3}{ }^{-}\right)$, and orthophosphate $\left(\mathrm{PO}_{4}{ }^{3-}\right.$ ) (data reported by Melo et al. (2019) for the period from December 2016 to December 2017), and saxitoxin (STX), microcystin (MC-LR), and abundant cyanobacteria biomass (data obtained in the present study)

Only $R$. raciborskii was positively correlated with STX and MC-LR, ordered in the quadrant opposite the $\mathrm{NO}_{3}{ }^{-}$gradient. Among the species analyzed, no other organism showed a positive correlation with the occurrence of cyanotoxins. Linear regression analysis applied to the $R$. raciborskii biomass and STX values $\left(R^{2}=0.21 ; p<0.05\right)$ confirmed that the presence of STX in the reservoir depended on the biomass of this species (Fig. 6a). In addition, there was a statistically significant inverse linear relation between $\mathrm{NO}_{3}$ - and $R$. raciborskii biomass $\left(\mathrm{R}^{2}=0.41 ; \mathrm{p}<0.05\right)$ (Fig. $6 \mathrm{~b}$ ). A negative correlation between $\mathrm{STX}$ and $\mathrm{NO}_{3}{ }^{-}$was observed in the Pearson correlation analysis $(r=-0.46)$ (Table S3) and the CCA (Fig. 5), confirming that $\mathrm{NO}_{3}{ }^{-}$directly affected the occurrence of $R$. raciborskii and, consequently, the presence of STX in the reservoir (the Supplementary Information (IS) Table 3-4 supports this results).

In the case of MC-LR, despite transforming the values using log10, the normality test $(\mathrm{W})$ indicated that the normality criterion was not met, so the linear effects of the variables on this toxin were not evaluated.

\section{Discussion}

The observed predominance of cyanobacteria in the Itupararanga reservoir was in agreement with previous findings (Cunha \& Calijuri 2011b; Casali et al. 2017), where the presence of $R$. raciborskii was identified in the reservoir, its main tributaries, and areas close to the dam. However, Casali et al. (2017) identified an opposite pattern in the dominance of $R$. raciborskii with respect to the climate, with high biomass values in the dry period $\left(>1.0 \times 10^{7} \mu \mathrm{m}^{3} \mathrm{~mL}^{-1}\right)$ and lower values in the rainy season $\left(\sim 5.0 \times 10^{6}\right.$

$\left.\mu \mathrm{m}^{3} \mathrm{~mL}^{-1}\right)$. Other studies have also reported the abundance of $R$. raciborskii in Brazilian reservoirs in the dry and rainy seasons, in addition to species of the genera Dolichospermum and Aphanizomenon (Figueredo \& Giani 2009; Moschini-Carlos et al. 2009; Sant'Anna et al. 2011; Bittencourt-Oliveira et al. 2014; Fonseca et al. 2014; Nishimura et al. 2014; Machado et al. 2016; Santos et al. 2018; Vicentin et al. 2018; Rodrigues et al. 2019).

The variation of the average cyanobacteria biomass among the samples revealed the influence of climatic conditions on these organisms. According to Melo et al. (2019), thermal stratification from point P4 to P7 was observed in October 2017, together with a substantial difference in levels of dissolved oxygen (DO) between the surface $\left(7 \mathrm{mg} \mathrm{L}^{-1}\right)$ and the bottom $\left(3 \mathrm{mg} \mathrm{L}^{-1}\right)$. In the same period, a decrease of the cyanobacteria biomass was observed at the sampling points where there was thermal stratification. According to Visser et al. (2016), thermal stratification tends to favor floating cyanobacteria, due to the weak mixing, allowing better access to light. In the present study, although the cyanobacteria biomass decreased at points where thermal stratification occurred, $R$. raciborskii and other species that also have 
aerotopes ( $D$. solitarium, $P$. isothrix, and $A$. gracile) were abundant. Furthermore, changes related to the availability of light, due to reduced water transparency, can have a significant influence on regulation of the dominance of cyanobacteria genera throughout the year (Vanderley et al. 2021).

The levels of STX and MC-LR identified were within the limits recommended by Brazilian legislation (Brazil, 2004) and the World Health Organization, of $3 \mu \mathrm{g} \mathrm{L}^{-1}$ for STX and $1 \mu \mathrm{g} \mathrm{L}^{-1}$ for MC (Chorus \& Bartram 1999). Casali et al. (2017) investigated the presence of STX as a function of the density of $R$. raciborskii in the Itupararanga reservoir, obtaining values between 0.04 and $0.20 \mu \mathrm{g} \mathrm{L}^{-1}$, which were close to those observed here, as well as strong correlation $(r=0.73, \mathrm{p}<0.001)$ between the biomass and STX values. In the present study, although significant linear correlation was observed between $R$. raciborskii biomass and STX, the effect was classified as moderate $\left(R^{2}=0.21 ; p<0.05\right)$.

The moderate linear relationship between the STX and biomass values could have been related to restrictive environmental conditions, which inhibited increase of the cyanobacteria volume and stimulated the production of cyanotoxins (Yamamoto et al. 2011; Lopes et al. 2012; Sarkar et al. 2020). For example, the phosphorus deficiency in the environment could have influenced the production of STX. Melo et al. (2019) observed a continuous decrease in the trophic status index towards the dam, influenced by phosphorus deficiency, classifying this region as meso-oligotrophic. Vargas (2012) tested different strains of $R$. raciborskii from the Itupararanga reservoir, finding that the production of STX by this species increased in an oligotrophic environment. These previous results corroborated the present findings, since higher levels of STX were observed in the region close to the Itupararanga reservoir dam (points P6 and P7).

It has been reported that environmental factors such as light, temperature, and nutrients have an important influence on the production of cyanotoxins, and that the consequences may be aggravated by climatic changes (Piccini et al. 2011; Paerl \& Paul 2012; Antunes et al. 2015; Huisman et al. 2018; Pham et al. 2020,Vanderley et al. 2021). Melo et al. (2019) identified high concentrations of TN (484.66 \pm $215.16 \mathrm{u} \mathrm{L} \mathrm{L}^{-1}$ ) in the Itupararanga reservoir during the same period as this study, reporting that the primary productivity of the reservoir was limited by phosphorus. The limitation by phosphorus in this reservoir has been reported in the last five years, prior to which there was co-limitation by phosphorus and nitrogen (Cunha \& Calijuri 2011a, 2011b; Taniwaki et al. 2013; Beghelli et al. 2016; Casali et al. 2017; Melo et al. 2019).

The inverse correlation between $\mathrm{NO}_{3}{ }^{-}$and the occurrence of $R$. raciborskii and STX may have been related to the energy expenditure required for these organisms to fix inorganic forms of nitrogen. In the case of diazotrophic cyanobacteria, such as $R$. raciborskii, this occurs in environments limited by phosphorus (Kenesi et al. 2009). According to Brentano et al. (2016), STX biosynthesis is regulated by stress situations related to the depletion of inorganic nitrogen in the environment, restricting biomass increase. The release of STX then has the function of contributing to homeostasis of the organism, regulating cell permeability (Brentano et al. 2016; Brêda-Alves et al. 2020; Sarkar et al. 2020). 
In the case of MC-LR, which was only detected at low concentrations, the maximum levels occurred in December 2016 and December 2017, considered rainy periods (Melo et al., 2019). At the same time, during these periods there was no abundance of species belonging to the genus Microcystis, but there was abundance of $P$. isothrix, Dolichospermum spp., and $P$. aerugineo-caeruleum. It is likely that the presence of $\mathrm{MC}$ in these periods was related to the occurrence of these organisms, since they are also potential producers of microcystins (Huisman et al. 2018).

In a study undertaken at the Billings complex reservoir and the Guarapiranga system in the metropolitan region of São Paulo, Moschini-Carlos et al. (2009) found moderate MC-LR concentrations of $0.28 \mu \mathrm{g} \mathrm{L}^{-1}$ in the rainy season and $0.57 \mu \mathrm{g} \mathrm{L}^{-1}$ in the dry season, with $P$. agardhii and Microcystis spp. being dominant. Bittencourt-Oliveira et al. (2014) found this toxin in $100 \%$ of the reservoirs studied in the Northeast region of Brazil, with high levels of $\mathrm{MC}$ ascribed to high biomasses of cyanobacteria of the genera P. agardhii, P. isothrix, and Microcystis spp..

\section{Conclusions}

The high contribution of Cyanophyceae in the Itupararanga reservoir was mainly due to the abundance of $R$. raciborskii. This species was the only one that had constant occurrence, being found in all the samples. The presence of STX was moderately influenced by $R$. raciborskii biomass, according to the classification parameters adopted. In this reservoir, a set of specific environmental conditions determined the variations of $R$. raciborskii biomass and STX. The facilitating environmental conditions included low availability of $\mathrm{NO}_{3}{ }^{-}$and phosphorus limitation. The trophic state could have been an additional factor, since the STX levels followed an increasing trend in the region close to the dam, characterized as mesooligotrophic. However, $R$. raciborskii was sensitive to thermal stratification, at the same time that STX levels increased. Hence, it appeared that STX was produced under conditions restrictive for the growth of $R$. raciborskii. These are important findings, since they provide information about the permanent occurrence of STX and $R$. raciborskii in an aquatic ecosystem with decrease of the trophic status index (upstream $\rightarrow$ downstream). Potentially toxic cyanobacteria had permanent abundance in the reservoir, with the alternation among them, due to changes in environmental conditions, implying the constant occurrence of cyanotoxins.

\section{Declarations}

Ethics approval and consent to participate: Not applicable

Consent for publication: Not applicable

Competing interests: The authors declare that they have no competing interests.

\section{Availability of data and materials}


All data generated or analysed during this study are included in this published article [and its supplementary information files].

Data reported previously for the Itupararanga reservoir (Melo et al. 2019) were used as a reference for the limnological characterization of the water, available at: https://doi.org/10.1029/2019WR025991

\section{Funding}

The authors are grateful for support provided by the Brazilian agencies FAPESP and CNPq for the financial assistance in the projects (processes 2016 / 17266-1 and 400305/2016) and Project DAAD / CAPES - Probal (Processes 99999.008107 / 2015-07, 88887.122769 / 2016-00 and 88887.141964 / 2017-00), and FAPESP - 16 / 15397-1

\section{Authors' contributions}

All authors contributed to the design of this study, as follows: Leila Machado: writing original draft, formal analysis; Fabiane Dörr: chromatographic analysis, formal analysis; Felipe Dörr: chromatographic analysis, formal analysis; Daniele Frascareli: sample collections, formal analysis; Darllene Melo: sample collections, formal analysis; Erik Gontijo: sample collections, formal analysis; Kurt Friese: formal analysis, funding acquisition; André Rosa: formal analysis, funding acquisition; Ernani Pinto: formal analysis, chromatographic analysis; Marcelo Pompêo: formal analysis, funding acquisition; Viviane MoschiniCarlos: formal analysis, funding acquisition. All authors commented on previous versions of the manuscript and read and approved the final manuscript.

\section{References}

AGUILERA, A.; BERRENDERO, E., KASTOVSKY, J.; ECHENIQUE, R.; SALERNO, G.L. (2018) The polyphasic analysis of two native Raphidiopsis isolates supports the unification of the genera Raphidiopsis and Cylindrospermopsis (Nostocales, Cyanobacteria). Phycologia, v. 57, n. 2, p. 130-146 https://doi.org/10.2216/17-2.1

Antunes, J. T., Leão, P. N. \& Vasconcelos, V. M. (2015).Cylindrospermopsis raciborskii: review of the distribution, phylogeography, and ecophysiology of a global invasive species. Front. Microbiol. 6, 473. doi: $10.3389 /$ fmicb.2015.00473

Beghelli, F. G. S., Frascareli, D., Pompêo, M. L. M., \&Moschini-Carlos, V. Trophic state evolution over 15 years in a tropical reservoir with low nitrogen concentrations and cyanobacteria predominance. Water, Air, \& Soil Pollution, 227(3), 95. (2016). https://doi.org/ 10.1007/s11270-016-2795-1

BITTENCOURT-OLIVEIRA, M. C.; PICCIN-SANTOS, V.; MOURA, A. N.; ARAGÃO-TAVARES, N. K. C.; CORDEIRO-ARAÚJO, M. K.. (2014) Cyanobacteria, microcystins and cylindrospermopsin in public drinking supply reservoirs of Brazil. An Acad Bras Cienc. https://doi.org/10.1590/0001-3765201302512 
Bittencourt-Oliveira, M.C., Chia, M.A., de Oliveira, H.S.B. et al. (2015) Allelopathic interactions between microcystin-producing and non-microcystin-producing cyanobacteria and green microalgae: implications for microcystins production. J Appl Phyco/27, 275-284. https://doi.org/10.1007/s10811-014-0326-2

BRASIL 2004.Portaria 518,de 25 de março de 2004. Diário Oficial da República Federativa do Brasil, Poder Executivo. Brasília (DF).

Brêda-Alves, F., de Oliveira Fernandes, V., Cordeiro-Araújo, M.K. et al. The combined effect of clethodim (herbicide) and nitrogen variation on allelopathic interactions between Microcystis aeruginosa and Raphidiopsis raciborskii. Environ Sci Pollut Res 28, 11528-11539 (2021). https://doi.org/10.1007/s11356-020-11367-x

BRENTANO, D. M.; GIEHL, E.L.H.; PETRUCIO, M.M.. (2016) Abiotic variables affect STX concentration in a meso-oligotrophic subtropical coastal lake dominated by Cylindrospermopsis raciborskii (Cyanophyceae). Harmful Algae. 56 22-28 https://doi.org/10.1016/j.hal.2016.03.017

CARDOSO-SILVA, S. ; MARIANI, C. F. ; POMPEO, M. L. M. (2015). Análise crítica da resolução CONAMA n 357 à luz da Diretiva Quadro da Água da comunidade europeia: estudo de caso (represa do Guarapiranga - São Paulo, Brasil). In: Marcelo Pompêo; Viviane Moschini-Carlos; Paula Y. Nishimura; Sheila CardosoSilva; Júlio L. Doval. (Org.). Ecologia de reservatórios e interfaces. 1ed.São Paulo: Universidade de São Paulo, v. 1, p. 367-375.

Carmichael, W. W. (2001) Health effects of toxin- producing cyanobacteria: "The CyanoHABs". Hum. Ecol. Risk Assess. 7, 1393-1407.

CASALI, S. P., SANTOS, A. C. A. D., FALCO, P. B. D., \& CALIJURI, M. D. C. (2017) Influence of environmental variables on saxitoxin yields by Cylindrospermopsis raciborskii in a mesotrophic subtropical reservoir. Journal of Water and Health, 15(4), 509-518. https://doi.org/ 10.2166/wh.2017.266

Christensen, V. G., Khan, E.. (2020) Freshwater neurotoxins and concerns for human, animal, and ecosystem health: A review of anatoxin-a and saxitoxin. Science of The Total Environment. Volume 736. https://doi.org/10.1016/j.scitotenv.2020.139515

CHORUS, I. \& J. BARTRAM. 1999. Toxic cyanobacteria in water-a guide to their public health consequences, monitoring and management. WHO, Spon Press, London.

COHEN, Jacob. (1988), Statistical power analysis for the behavioral sciences. Hillsdale, NJ, Erlbaum.

CUNHA, D. G. F., \& CALIJURI, M. D. Limiting factors for phytoplankton growth in subtropical reservoirs: The effect of light and nutrient availability in different longitudinal compartments. Lake and Reservoir Management, 27(2), 162-172. (2011a).

CUNHA, D. G. F., \& CALIJURI, M. D. C. Variação sazonal dos grupos funcionais fitoplanctônicos em braços de um reservatório tropical de usos múltiplos no estado de São Paulo (Brasil). Acta Botânica Brasílica, 
Cunha, D. G. F., Calijuri, M. D. C., \& Lamparelli, M. C. (2013). A trophic state index for tropical/subtropical reservoirs (TSItsr). Ecological Engineering, 60, 126-134. https://doi.org/10.1016/j.ecoleng.2013.07.058

Facciponte, D. N. et al. (2018) Identifying aerosolized cyanobacteria in the human respiratory tract: A proposed mechanism for cyanotoxin-associated diseases, Science of The Total Environment, Volume 645, Pages 1003-1013. https://doi.org/10.1016/j.scitotenv.2018.07.226

FIGUEREDO, C.C. \& GIANI, A. (2009) Phytoplankton community in the tropical lake of Lagoa Santa (Brazil): Conditions favoring a persistent bloom of Cylindrospermopsis raciborskii. Limnologica 39: 264272. https://doi.org/10.1016/j.limno.2009.06.009

FONSECA, B.M.; FERRAGUT, C.; TUCCI, A.; CROSSETTI, L.O.; FERRARI, F.; BICUDO, D. de C.; SANT'ANNA, C.L. e BICUDO, C.E. de. (2014) Biovolume de cianobactérias e algas de reservatórios tropicais do Brasil com diferentes estados tróficos. Hoehnea, 41(1), 9-30. https://doi.org/10.1590/S223689062014000100002

Funari, E.; Manganelli, M.; Buratti, F.M.; Testai, E.. (2017) Cyanobacteria blooms in water: Italian guidelines to assess and manage the risk associated to bathing and recreational activities, Science of The Total Environment,Volume 598, Pages 867-880. doi: 10.1016/j.scitotenv.2017.03.232

HILLEBRAND, H.; DÜRSELEN, C.-D.; KIRSCHTEL, D.; POLLINGHER, U. e ZOHARY, T. (1999) Biovolume calculation for pelagic and benthic microalgae. Journal of Phycology, 35: 403-424.

HUISMAN, Jef; CODD, G. A.; PAERL, H. W.; IBELINGS, B. W.; VERSPAGEN, J. M. H.; VISSER, P. M. P.. (2018) Cyanobacterial blooms - Nature Reviews Microbiology - volume 16, pages 471-483. https://doi.org/10.1038/s41579-018-0040-1

Jones, G.J. and Negri, A.P. (1997) Persistence and degradation of cyanobacterial paralytic shellfish poisons (PSPs) in freshwaters. Wat. Res., 31, 525-533. https://doi.org/10.1016/S0043-1354(96)00134-0

Kenesi, G., Shafik, H.M., Kovács, A.W., Herodek, S., Présing, M. (2009) Effect of nitrogen forms on growth, cell composition and N2 fixation of Cylindrospermopsis raciborskii in phosphorus-limited chemostat cultures. Hydrobiologia. Volume 623, Issue 1, Pages 191-202. https://doi.org/10.1007/s10750-008-96579

$\mathrm{KIM}$, J. et al. Stability, accuracy and efficiency of sequential methods for coupled flow and geomechanics. In: SPE reservoir simulation symposium. Society of Petroleum Engineers, 2009.

KOMÁREK, J.; ANAGNOSTIDIS, K. (1999) Cyanoprokaryota 1: teil: chroococcales. In: ETTL, H. et al. (Ed.). Süsswasser von Mitteleuropa. [S.I]: Elsevier. p. 548. 
KOMÁREK, J.; ANAGNOSTIDIS, K. Cyanoprokayota 2: teil: oscillatoriales. In: BRIDEL, B. et al. (2005). Subwasserflora von mitteleuropa. [S.I]: Elsevier, p. 759.

Lopes VR, Ramos V, Martins A, Sousa M, Welker M, Antunes A, Vasconcelos VM. (2012) Phylogenetic, chemical and morphological diversity of cyanobacteria from Portuguese temperate estuaries. Mar Environ Res. Feb;73:7-16. doi: 10.1016/j.marenvres.2011.10.005.

MACHADO, L.S., SANTOS, L.G., LOPEZ-DOVAL, J.C., POMPEO, M.L.M. and MOSCHINICARLOS, V. (2016) Fatores ambientais relacionados à ocorrência de cianobactérias potencialmente tóxicas no reservatório de Guarapiranga. Revista Ambiente \& Água, 11(4), 810-818. http://dx.doi. org/10.4136/ambi-agua.1941.

Melo, D. S., Gontijo, E. S. J., Frascareli, D., Simonetti, V. C., Machado, L. S., Barth, J. A. C., et al (2019). Selforganizing maps for evaluation of biogeochemical processes and temporal variations in water quality of subtropical reservoirs. Water Resources Research, 55, 10268- 10281.

https://doi.org/10.1029/2019WR025991

Mello, M. M., Soares, M. C. S., Roland, F., Lürling, M. (2012) Growth inhibition and colony formation in the cyanobacterium Microcystis aeruginosa induced by the cyanobacterium Cylindrospermopsis raciborskii, Journal of Plankton Research, Volume 34, Issue 11, Pages 987-994, https://doi.org/10.1093/plankt/fbs056

Merel, S. et al. (2013) State of knowledge and concerns on cyanobacterial blooms and cyanotoxins. Environ. Int. 59, 303-327. https://doi.org/10.1016/j.envint.2013.06.013

MOSCHINI-CARLOS, VIVIANE; BORTOLI, STELLA; PINTO, ERNANI; NISHIMURA, PAULA YURI; GOMES DE FREITAS, LEANDRO; POMPÊO, MARCELO L. M.; DÖRR, FELIPE. (2009) Cyanobacteria and Cyanotoxin in the Billings Reservoir (Sâo Paulo, SP, Brazil). Limnética, Vol. 28, Núm. 2, p. 273-282. DOI: 10.23818/limn.28.23

Moschini-CARLOS, V.; DE FREITAS, L. G.; POMPÊO, M.. (2010) Limnological evaluation of water in the Rio Grande and Taquacetuba branches of the Billings Complex (São Paulo, Brazil) and management implications. Ambiente e Agua - An Interdisciplinary Journal of Applied Science, [S.I.], v. 5, n. 3, p. 47-59.

Mowe, M. A., Mitrovic, S. M., Lim, R. P., Furey, A., and Yeo, D. C. (2015b). Tropical cyanobacterial blooms: a review of prevalence, problem taxa, toxins and influencing environmental factors. Journal of Limnology 74(2), 205-224. DOI:10.4081/jlimnol.2014.1005

NISHIMURA, P.Y.; MEIRINHO, P.A.; MOSCHINI-CARLOS, V.; POMPÊO, M.L.M. (2014) Does the plankton community follow the water quality hetero geneity in a tropical urban reservoir (Guarapiranga reservoir, São Paulo, Brazil) Limnetica, 33(2): 263-280.

NOGUEIRA, I.S.; GAMA JÚNIOR, W.A. e D’ALESSANDRO, E.B. Cianobactérias planctônicas de um lago artificial urbano na cidade de Goiânia, GO. Rev. Bras. Bot., 2011, 34(4), 575-592. 
OKSANEN, J. F., BLANCHET, G., FRIENDLY, M., KINDT, R., LEGENDRE, P., MCGLINN, D., MINCHIN, P. R., R., O'HARA, B., SIMPSON, G. L., SOLYMOS, P., STEVENS, M. H. H., SZOECS, E., WAGNER, H. Vegan. R Community Ecology Package, version 2.5-2. (2018).

PADISÁK, J.; CROSSETTI, L.O. e NASELLI-FLORES, L. (2009) Use and misuse in the application of the phytoplankton functional classification: a critical review with updates. Hydrobiologia, 621(1): 1-19. https://doi.org/10.1007/s10750-008-9645-0

PAERL, H. W. E V. J. PAUL. (2012) Climate change: links to global expansion of harmful cyanobacteria. Water Research 46:1349-1363. doi:10.1016/j.watres.2011.08.002

Pedrazzi, F. J. D. M., Conceição, F. T. D., Sardinha, D. D. S., Moschini-Carlos, V., \& Pompêo, M. (2013). Spatial and temporal quality ofwater in the Itupararanga Reservoir, Alto Sorocaba Basin (SP), Brazil. Journal of Water Resource and Protection, 5(1), 64-71. https://doi.org/10.4236/jwarp.2013.51008

Pedrosa, C.S.G. Souza, R.Q., Gomes, T.A., Lima, C.V.F., Ledur, P.F., Karmirian, K., et al. (2020) The cyanobacterial saxitoxin exacerbates neural cell death and brain malformations induced by Zika virus. PLoS Negl Trop Dis 14(3): https://doi.org/10.1371/journal.pntd.0008060

Pham, TL., Tran, T.H.Y., Shimizu, K. et al. (2020) Toxic cyanobacteria and microcystin dynamics in a tropical reservoir: assessing the influence of environmental variables. Environ Sci Pollut Res. https://doi.org/10.1007/s11356-020-10826-9

Piccini, C., Aubriot, L., Fabre, A., Amaral, V., González-Piana, M., Gianni, A., et al.(2011).Geneticandecophysiological differences of South American Cylindrospermopsis raciborskii isolates support the hypothesis of multiple ecotypes. HarmfulAlgae10,644-653.doi:10.1016/j.hal.2011.04.016

Pompêo, M., Moschini-Carlos, V., Bitencourt, M.D. et al. (2021) Water quality assessment using Sentinel-2 imagery with estimates of chlorophyll a, Secchi disk depth, and Cyanobacteria cell number: the Cantareira System reservoirs (São Paulo, Brazil). Environ Sci Pollut Res. https://doi.org/10.1007/s11356-021-12975$\mathrm{X}$

REYNOLDS, C.S. Ecology of phytoplankton. Cambrigde: Cambrigde University Press, 2006.

RODRIGUES, Eduardo Henrique Costa et al . (2019) Phytoplankton, Trophic State and Ecological Potential in reservoirs in the State of São Paulo, Brazil. Rev. Ambient. Água, Taubaté, v. 14, n. 5, e2428. https://doi.org/10.4136/ambi-agua.2428.

ROSA, A. H., SILVA, Â. A. M. J., MELO, C. D. A., MOSCHINI, V., CARLOS, M., GUANDIQUE, E. G., \& FRACETO, L. F.. (2015) Diagnóstico ambiental e avaliação de uso e ocupação do solo visando a sustentabilidade da represa de Itupararanga, importante área da bacia do médio Tietê. Ecologia de reservatórios e interfaces, (pp. 213-231). São Paulo: Instituto de Biociências da Universidade de São Paulo. 
Sant'Anna, C.L., de Carvalho, L.R., Fiore, M.F. et al. (2011) Highly Toxic Microcystis aeruginosa Strain, Isolated from São Paulo-Brazil, Produce Hepatotoxins and Paralytic Shellfish Poison Neurotoxins. Neurotox Res 19, 389-402. https://doi.org/10.1007/s12640-010-9177-z

SANT'ANNA, C.L.; AZEVEDO, M.T. de P.; AGUJARO, L.F.; CARVALHO, M. do C.; CARVALHO, L.R. de, e SOUZA, R.C.R. de. (2006) Manual ilustrado para identificação e contagem de cianobactérias planctônicas de águas continentais brasileiras. Interciência; São Paulo: Sociedade Brasileira de Ficologia, 58 p.

Sant’Anna, C.L.; Azevedo, M.T.P.; Senna, P.A.C.; Komárek, J. \& Komárková, J.. (2004) Planktic Cyanobacteria from São Paulo State, Brazil: Chroococcales. Revista Brasileira de Botânica 27: 213-227. https://doi.org/10.1590/S0100-84042004000200002

Sant'Anna, C.L.; Tucci, A.; Azevedo, M.T.P.; Melcher, S.S.; Werner, V.R.; Malone, C.F.S.; Rossini, E.F.; Jacinavicius, F.R.; Hentschke, G.S.; Osti, J.A.S.; Santos, K.R.S.; Gama-Júnior, W.A.; Rosal, C. \& Adame, G.. (2012) Atlas de cianobactérias e microalgas de águas continentais brasileiras. Publicação eletrônica, Instituto de Botânica, Núcleo de Pesquisa em Ficologia.

Santos, L. G., Machado L.D.S., Moschini-Carlos, V.\&Pompêo, M.. (2018) Os grupos funcionais fitoplanctônicos nos reservatórios do Sistema Cantareira, São Paulo, Brasil. Iheringia: Série Botânica. v. 73, n. 2. DOI 10.21826/2446-8231201873205

Sarkar, A., Rajarathinam, R. \& Venkateshan, R.B. (2021) A comparative assessment of growth, pigment and enhanced lipid production by two toxic freshwater cyanobacteria Anabaena circinalis FSS 124 and Cylindrospermopsis raciborskii FSS 127 under various combinations of nitrogen and phosphorous inputs. Environ Sci Pollut Res 28, 15923-15933. https://doi.org/10.1007/s11356-020-11754-4

SUN, J. e LIU, D. (2003) Geometric models for calculating cell biovolume and surface area for phytoplankton. Journal of Plankton Research, 25(11), 1331-1346. https://doi.org/10.1093/plankt/fbg096

Taniwaki, R., Rosa,A., De Lima, R.,Maruyama, C.,Secchin,L., Calijuri,M.,\& Moschini-Carlos, V.(2013). A influência do uso e ocupação do solo na qualidade e genotoxicidade da água no reservatório de Itupararanga, São Paulo, Brasil. Interciencia, 38(3), 164-170.

Trung, B., Thanh-Son, D., Truong-Giang, V., Lürling, M.. (2018) Warming Affects Growth Rates and Microcystin Production in Tropical Bloom-Forming Microcystis Strains. Toxins, 10, 123; doi:10.3390/toxins10030123

Vanderley, R.F., Ger, K.A., Becker, V. et al. (2021) Abiotic factors driving cyanobacterial biomass and composition under perennial bloom conditions in tropical latitudes. Hydrobiologia 848, 943-960. https://doi.org/10.1007/s10750-020-04504-7

Vicentin, A. M.,Rodrigues, E. H. C.,Moschini-Carlos, V., POMPEO, M.L.M.. (2018) Is it possible to evaluate the ecological status of a reservoir using the phytoplankton community?Acta Limnologica Brasiliensia, 
VISSER, P. M. , VERSPAGEN, J. M.H. , SANDRINI, G. , STAL, L. J. , MATTHIJS, H. C.P. , DAVIS, T. W. , PAERL, H. W. , HUISMAN, J.. (2016) How rising CO2 and global warming may stimulate harmful cyanobacterial blooms. Harmful Algae, Volume 54, Pages 145-159, ISSN 1568-9883, https://doi.org/10.1016/j.hal.2015.12.006.

WETZEL, R. G. \& LIKENS, G. E. (2000) Composition and Biomass of Phytoplankton. In: Limnological Analyses. Springer, New York, NY. https://doi.org/10.1007/978-1-4757-3250-4_10

WHO. (2017) Guidelines for drinking-water quality: fourth edition incorporating the first addendum.Geneva: World Health Organization.

Yamamoto Y, Shiah FK, Chen TL (2011) Importance of large colony formation in bloom-forming cyanobacteria to dominate in eutrophic ponds. Ann Limnol Int J Lim 47:167-173. https://doi.org/10.1051/limn/2011013

\section{Figures}

Sampling sites (reservoir)

Sampling sites (inflows)

Reservoir

Rivers

$\sum$ Catchment boundaries

Buffer zone $(1 \mathrm{~km})$

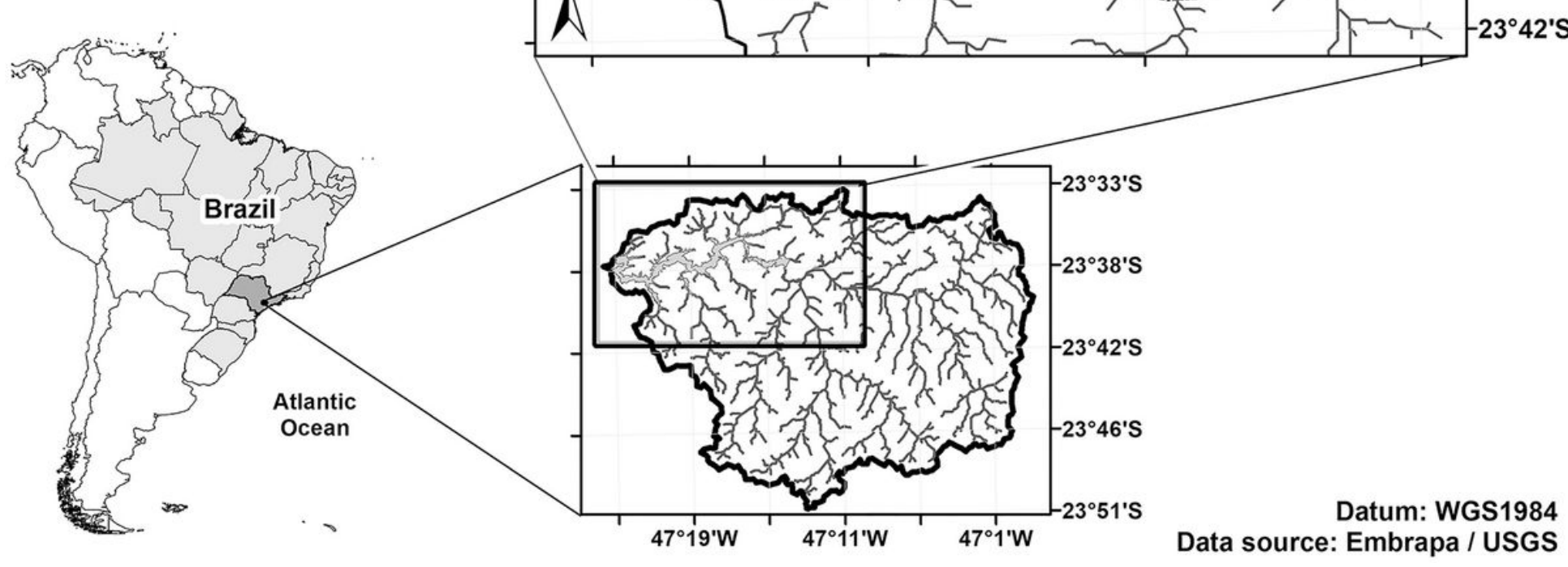


Figure 1

Map of the Itupararanga reservoir and locations of the sampling points. Original source: Melo et al. (2019)

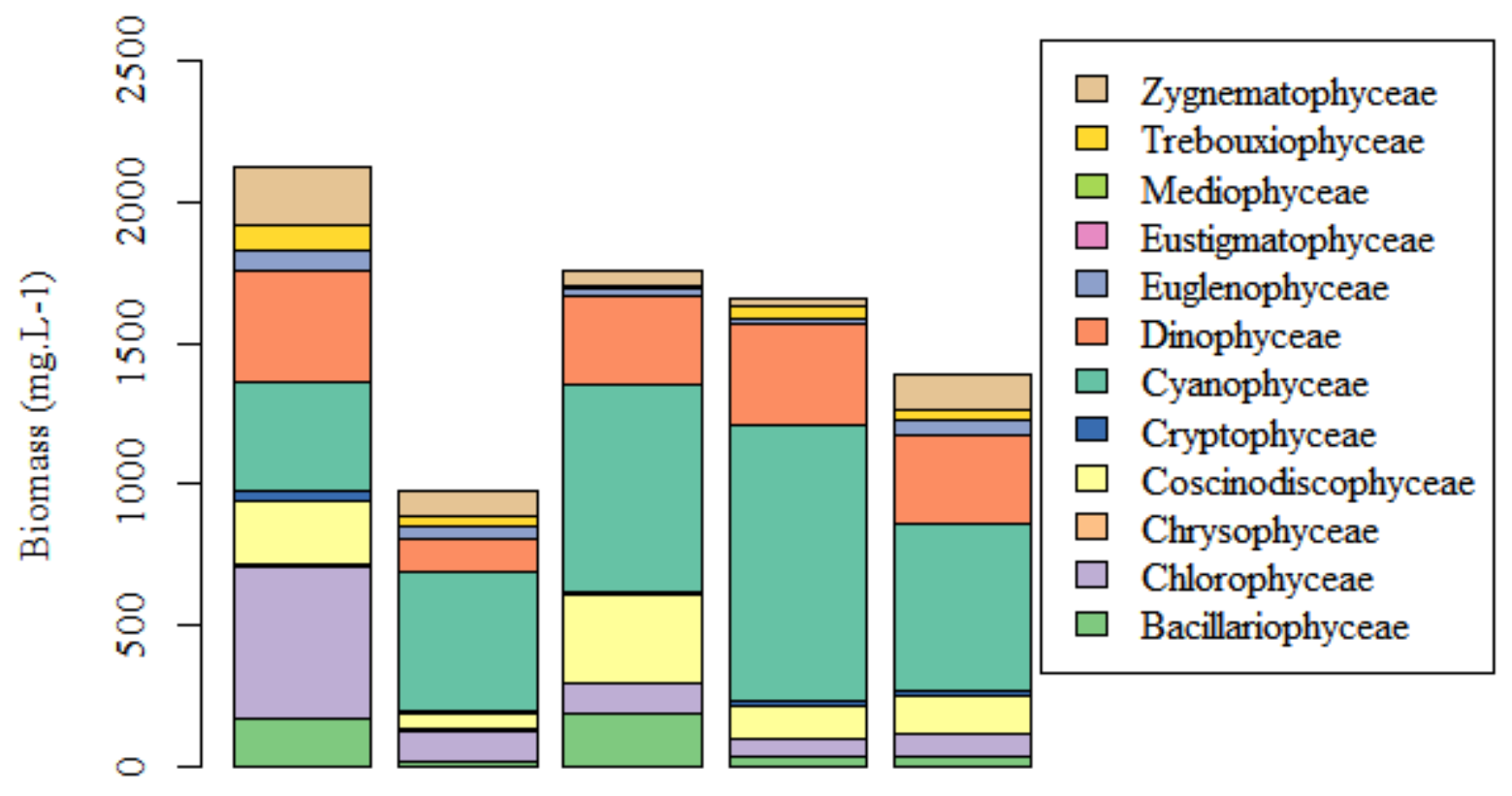

Dec/16 $\quad$ Mar/17 $\quad$ Aug/17 $\quad$ Oct/17 $\quad$ Dec/17

Figure 2

Total biomasses of the phytoplankton classes in the Itupararanga reservoir during the periods December 2016, March 2017, August 2017, October 2017, and December 2017 


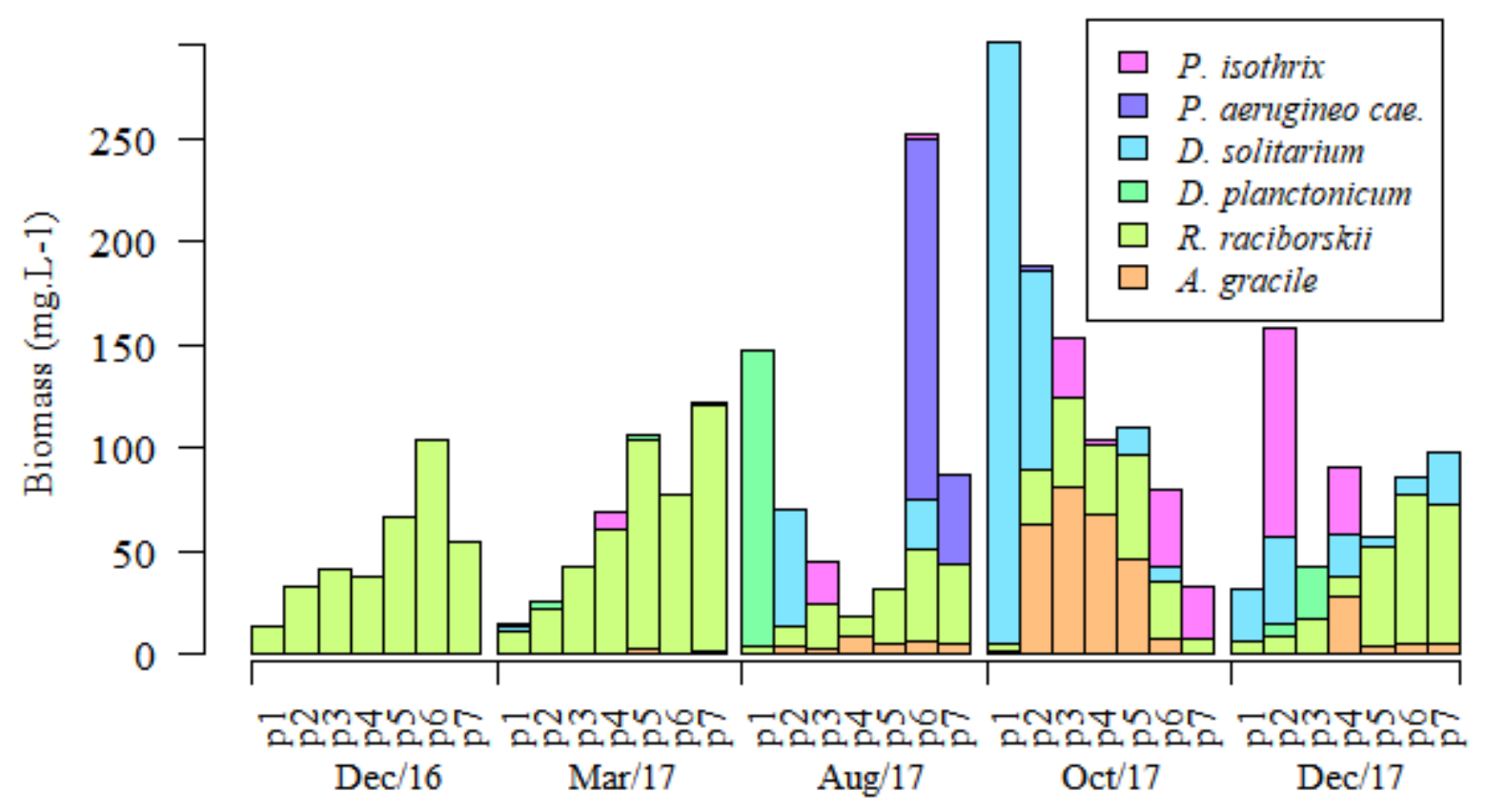

Figure 3

Biomasses of abundant cyanobacteria ( $>5 \%$ ) during the periods December 2016, March 2017, August 2017, October 2017, and December 2017
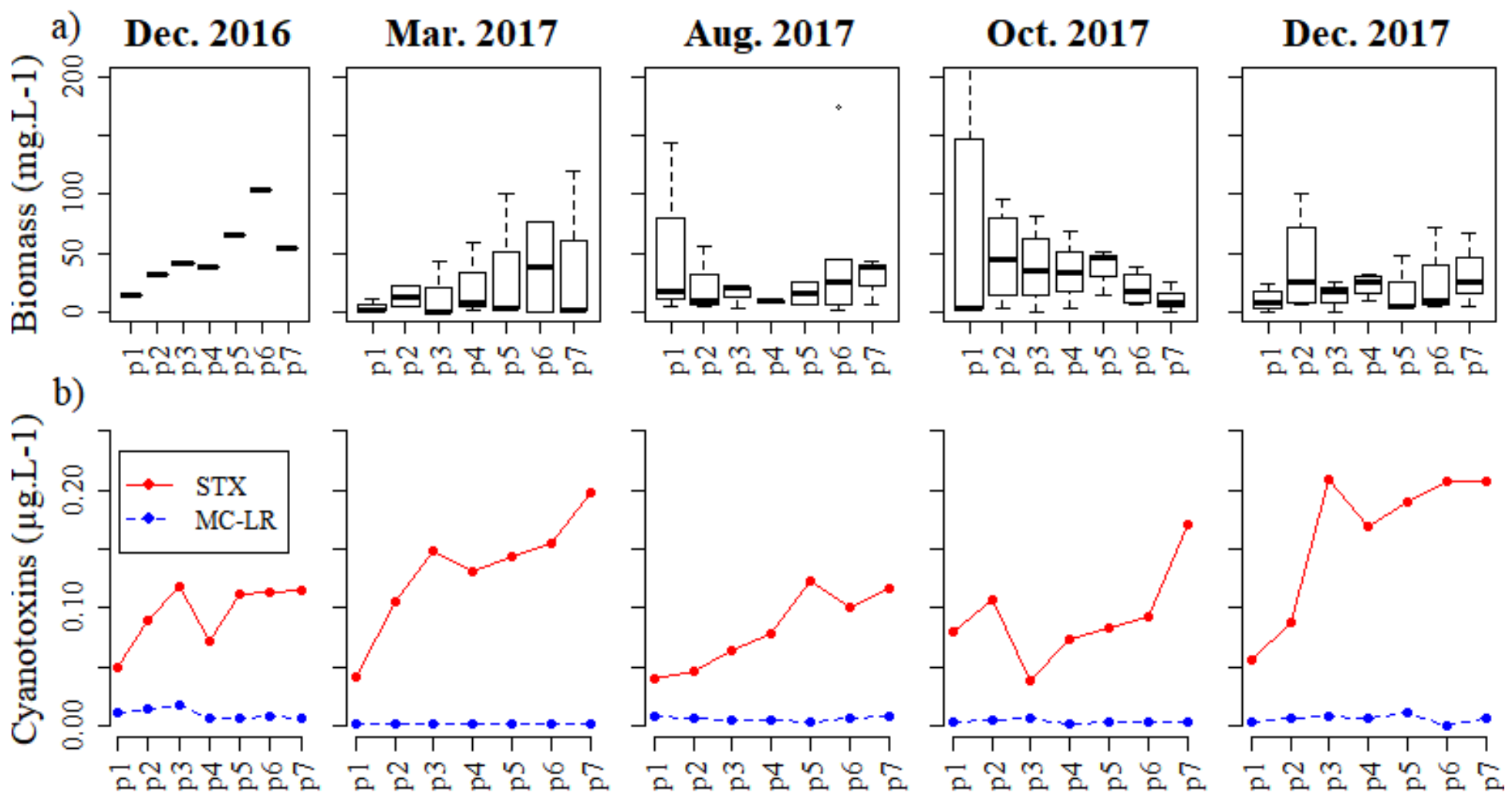

Figure 4 
a) Box plots of cyanobacteria biomasses (mg L-1) in the different collections, and b) contents ( $\mu \mathrm{g} L-1)$ of saxitoxin (STX) and microcystin (MC-LR)

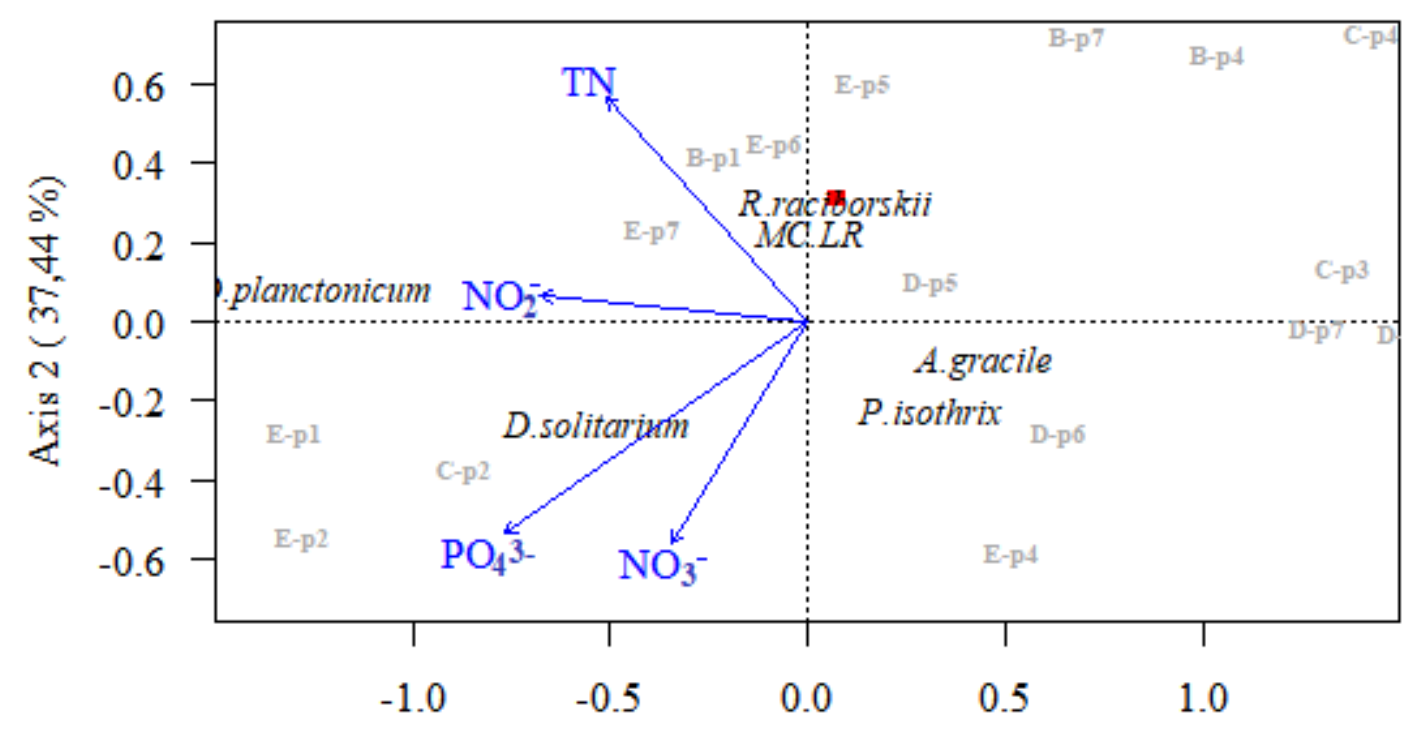

Axis $1(42,06 \%)$

Figure 5

CCA biplot with the following variables: total nitrogen (TN), nitrite (NO2-), nitrate (NO3-), orthophosphate (PO43-), microcystin (MC-LR), saxitoxin (STX, represented by the symbol " $\mathbf{\square}$ " in red), and abundant cyanobacteria biomass

a)

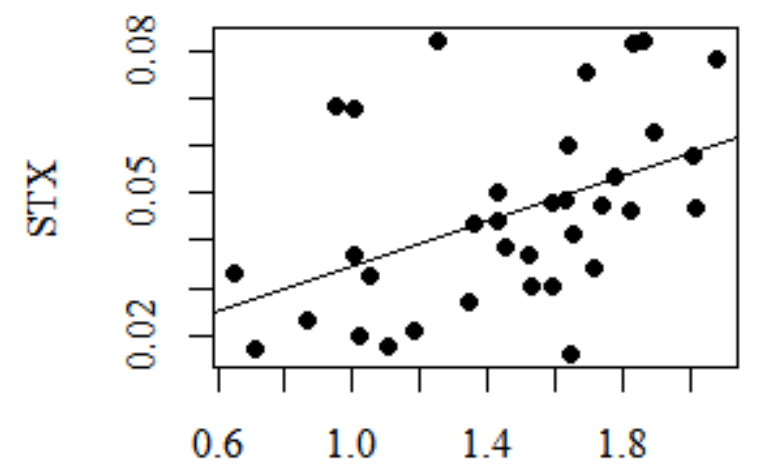

R. raciborskii b)

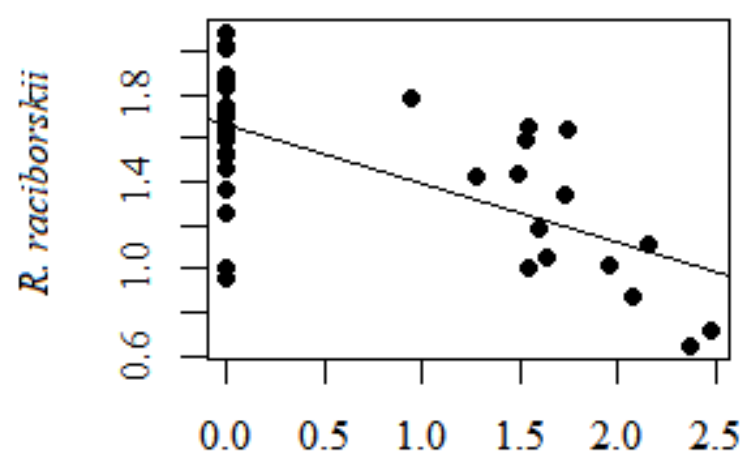

$\mathrm{NO}_{3}^{-}$

Figure 6 
Simple linear regression between (a) R. raciborskii and STX $(R 2=0.21 ; p<0.05)$, and (b) NO3- and $R$. raciborskii $(\mathrm{R} 2=0.41 ; \mathrm{p}<0.05)$

\section{Supplementary Files}

This is a list of supplementary files associated with this preprint. Click to download.

- SupplementarymaterialMachadoetal.pdf 